\title{
Correction to: The Mamluk's Best Friend: The Mounts of the Military Elite of Egypt and Syria in the Late Middle-Ages
}

Reuven Amitai and Gila Kahila Bar-Gal

\section{Correction to:}

Chapter 9 in: R. Kowner et al. (eds.), Animals and Human Society in Asia, The Palgrave Macmillan Animal Ethics Series, https://doi.org/10.1007/978-3-030-24363-0_9

In the original version of the book, the following belated correction was made: the title of Chapter 9 has been changed from "The Mamluk's Best Friend: The Mounts of the Military Elite of Egypt and Eurasian Steppe in the Late Middle-Ages" to "The Mamluk's Best Friend: The Mounts of the Military Elite of Egypt and Syria in the Late Middle-Ages". The correction to the book has been updated with the change.

\footnotetext{
The updated version of this chapter can be found at https://doi.org/10.1007/978-3-030-24363-0_9

(C) The Author(s) 2019

R. Kowner et al. (eds.), Animals and Human Society in Asia, The Palgrave Macmillan Animal Ethics Series, https://doi.org/10.1007/978-3-030-24363-0_14
} 